\title{
Quality Monitoring and Evaluation System of the Practical Teaching of Food Science and Engineering Specialty in Local Application-Oriented Undergraduate Colleges under the Background of New Engineering-A Case Study of Bengbu University
}

\author{
Yahua Wu, Ningning Yang, Yazhong Shi, Gailing Wang \\ College of Food and Biological Engineering, Bengbu University, Bengbu, China \\ Email: wyh@bbc.edu.cn,ynn@bbc.edu.cn, syz@bbc.edu.cn, wgl@bbc.edu.cn
}

How to cite this paper: Wu, Y. H., Yang, N. N., Shi, Y. Z., \& Wang, G. L. (2021). Quality Monitoring and Evaluation System of the Practical Teaching of Food Science and Engineering Specialty in Local Application-Oriented Undergraduate Colleges under the Background of New Engineering-A Case Study of Bengbu University. Open Journal of Social Sciences, 9, 181-190. https://doi.org/10.4236/jss.2021.96015

Received: April 26, 2021

Accepted: June 20, 2021

Published: June 23, 2021

Copyright $\odot 2021$ by author(s) and Scientific Research Publishing Inc. This work is licensed under the Creative Commons Attribution International License (CC BY 4.0).

\begin{abstract}
Taking Bengbu University as an example, this paper analyzed the practical teaching system, practical teaching management system, practical teaching quality standard system and practical teaching quality evaluation system of food science and engineering major, and also combed the effect of practical teaching quality monitoring and evaluation system under the background of new engineering development. It has been demonstrated that the practical teaching quality monitoring and evaluation system of this specialty is scientific and reasonable, which has a hand in standardizing the practical teaching management and the practical teaching process and improving the quality of practical teaching.
\end{abstract}

\section{Keywords}

New Engineering, Food Science and Engineering Major, Practical Teaching, Quality Monitoring and Evaluation System

\section{Introduction}

After the Ministry of Education of China promoted the construction of "New Engineering" (Department of Higher Education, the Ministry of Education. 2017), many local applied-type universities (or applied undergraduate university) are underway to vigorously probe the talent development mode under the 
background of "New Engineering" and set up a practical teaching quality monitoring and evaluation system combined with their own features for the past few years (Han et al., 2011; Xian et al., 2018; Xiang et al., 2020; Liu et al., 2019; Liu \& Wang, 2016). The Food Science and Engineering major is an applied major with high requirements for students' practical professional skills. Practical teaching is an important means to cultivate students' practical professional skills (Niu et al., 2013) and plays an important role in the training of food science and engineering professionals (Liu et al., 2011). In this paper, Bengbu University is taken as an example to analyze the quality monitoring and evaluation system of practical teaching of Food Science and Engineering major under the background of "New Engineering", which could provide some reference for the construction of "New engineering" in other local application-oriented colleges and universities in China. This study on the Food Science and Engineering major development and construction under the "New Engineering" background in China can also provide some valuable references for other developing countries on the issues of how to build and further develop the Food Science and Engineering and also other related universities majors.

\section{Practical Teaching System}

The practical teaching system of Food Science and Engineering major in Bengbu University can be divided into basic practice, professional practice, comprehensive practice, innovative practice and employment and entrepreneurship (as Figure 1).

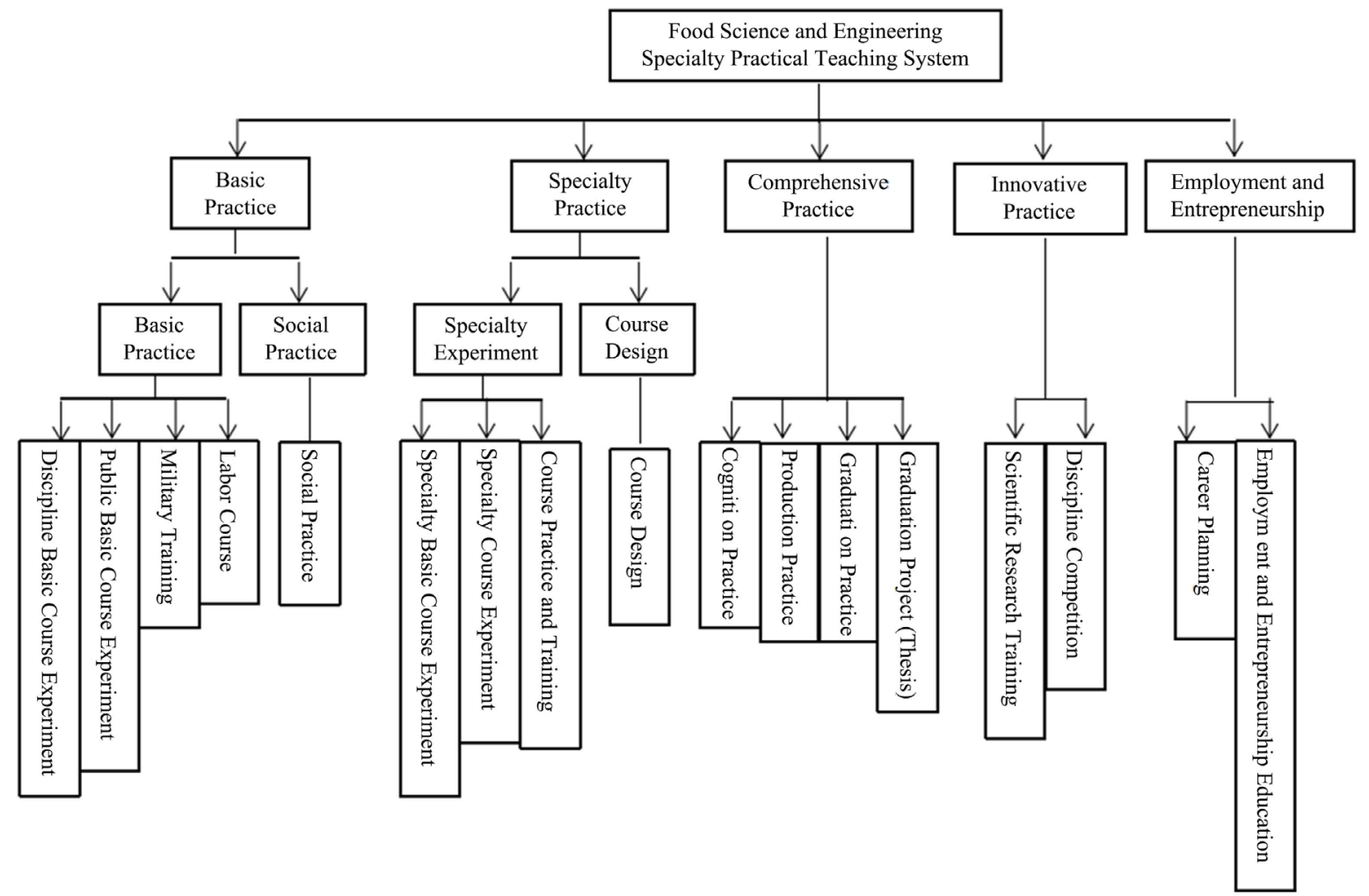

Figure 1. Composition of practical teaching system of food science and engineering specialty in Bengbu University. 
Basic practice includes Basic Practice and Social Practice. Basic practice is further divided into Discipline Basic Course Experiment, Public Basic Course Experiment, Military Training and Labor course. Specialty Practice includes Specialty Experiment and Course Design. Among them, Specialty Experiment includes Specialty Basic Course Experiment, Specialty Course Experiment and Course Practice and Training. Comprehensive Practice includes Cognition Practice, Production Practice, Graduation Practice, and Graduation Project (Thesis). Invocative Practice is composed by Scientific Research Training and Discipline Competition, and Employment and Entrepreneurship is composed by Career Planning and Employment and Entrepreneurship Education. Through the above practical teaching system, students are guided to apply the knowledge they have learned to solve complex engineering problems in the process of food production, and further reflect the sense of innovation, and consider social, health, safety, legal, cultural and environmental factors.

\section{Practical Teaching Management System}

\subsection{Constructing a Two-Level Management System}

Bengbu University has come up with a relatively complete two-level management system (university-level management system and college-level management system), in order to comprehensively supervise and evaluate the whole process of food science and engineering practical teaching. The university-level practical teaching management system is comprised of President, Vice President in charge of teaching, Academic Affairs Office, Teaching Quality Monitoring Office and University-level Teaching Supervision Group. In particular, Teaching Quality Monitoring Office, independent of the Academic Affairs Office, holistically monitors the quality of practical teaching, and also inspects the organization and implementation process of practical teaching from time to time, issues the results of supervision and inspection on a regular basis, and brings up opinions and suggestions for a better teaching, in addition to comprehensively monitoring each implementation link of theoretical teaching.

The college-level practical teaching management system consists of President of College of Food and Bioengineering, Vice President of Teaching, Secretary, Teaching Secretary, Director of Teaching and Research Office and Teaching Supervision Group of the college. Particularly, the President, Vice President of Teaching, Secretary and Teaching Secretary are chiefly in charge of the overall planning of major practice teaching, and the Director of Teaching and Research Office and the Director of Laboratory of the specific development and implementation of practical teaching tasks. It is the responsibility of the Teaching Supervision Group, comprising teachers with abundant working experience, to collect the opinions and suggestions from both of teachers and students, and further evaluate the fulfillment of practical teaching and teaching quality, and finally provide timely feedback to relevant teachers, and boost the improvement of practical teaching level, by ways of attending lectures, organizing inspections, holding symposiums and other forms. 


\subsection{Upgrading the Teaching Management Documents}

According to the training practice of innovative talents under the background of "New Engineering", Bengbu university has revised and improved their teaching management documents (Table 1) on the basis of 2014 practical teaching management documents (Table 2). These teaching management documents regulate

Table 1. 2019 practical teaching management documents of Bengbu University (part).

\begin{tabular}{|c|c|}
\hline No. & Practical Teaching Management Documents \\
\hline 1 & Experimental Teaching Standard of Bengbu University \\
\hline 2 & Management Measures for Laboratory Opening of Bengbu University \\
\hline 3 & Management Measures for Experimental (Practical) Teaching Center of Bengbu University \\
\hline 4 & $\begin{array}{l}\text { Identification and Implementation of Comprehensive and Designed Experimental Projects } \\
\text { in Bengbu University }\end{array}$ \\
\hline 5 & Measures for the Management of Practice Teaching in Bengbu University \\
\hline 6 & $\begin{array}{l}\text { Management Measures for Off Campus Practice (Training) Base Construction of Bengbu } \\
\text { University }\end{array}$ \\
\hline 7 & Management Measures for Undergraduate Course Design of Bengbu University \\
\hline 8 & $\begin{array}{l}\text { Measures for the Administration of Practical Teaching Activities in Primary School of } \\
\text { Bengbu University (Revised) }\end{array}$ \\
\hline 9 & $\begin{array}{l}\text { Management Measures for Undergraduate Graduation Project (Thesis) of Bengbu } \\
\text { University (Revised) }\end{array}$ \\
\hline 10 & $\begin{array}{l}\text { Credit Recognition and Management of Undergraduate Innovation and Entrepreneurship in } \\
\text { Bengbu University }\end{array}$ \\
\hline 11 & Bengbu University Deepen the Reform of Entrepreneurship Education for College Students \\
\hline 12 & Bengbu University Students' Social Responsibility Education and Training Program \\
\hline 13 & $\begin{array}{l}\text { Credit Management Measures for Social Responsibility Education and Training of College } \\
\text { Students in Bengbu University }\end{array}$ \\
\hline 14 & Opinions of Bengbu University on Strengthening the Supervision of Teaching Quality \\
\hline 15 & $\begin{array}{l}\text { Teaching Quality Monitoring and Guarantee System Construction Outline of Bengbu } \\
\text { University }\end{array}$ \\
\hline 16 & Quality Standard of Main Teaching Links of Applied Talents Training in Bengbu University \\
\hline 17 & $\begin{array}{l}\text { Opinions on the Implementation of Undergraduate Teaching Supervision in Bengbu } \\
\text { University }\end{array}$ \\
\hline 18 & Evaluation Method of Classroom Teaching Quality in Bengbu University \\
\hline 19 & $\begin{array}{l}\text { Measures for the Implementation of Students Online Teaching Evaluation in Bengbu } \\
\text { University }\end{array}$ \\
\hline 20 & Management Measures for Teachers' Evaluation of Bengbu University \\
\hline 21 & The System of Leaders' Attending Class in Bengbu University \\
\hline 22 & Opinions of Bengbu University on Further Strengthening Practical Teaching \\
\hline 23 & Opinions of Bengbu University on Strengthening the Construction of Teaching Style \\
\hline 24 & Teaching Standard of Bengbu University \\
\hline 25 & $\begin{array}{l}\text { Measures for the Management of Industry University Research Cooperation Education in } \\
\text { Bengbu University }\end{array}$ \\
\hline
\end{tabular}


Table 2. 2014 practical teaching management documents of Bengbu University (part).

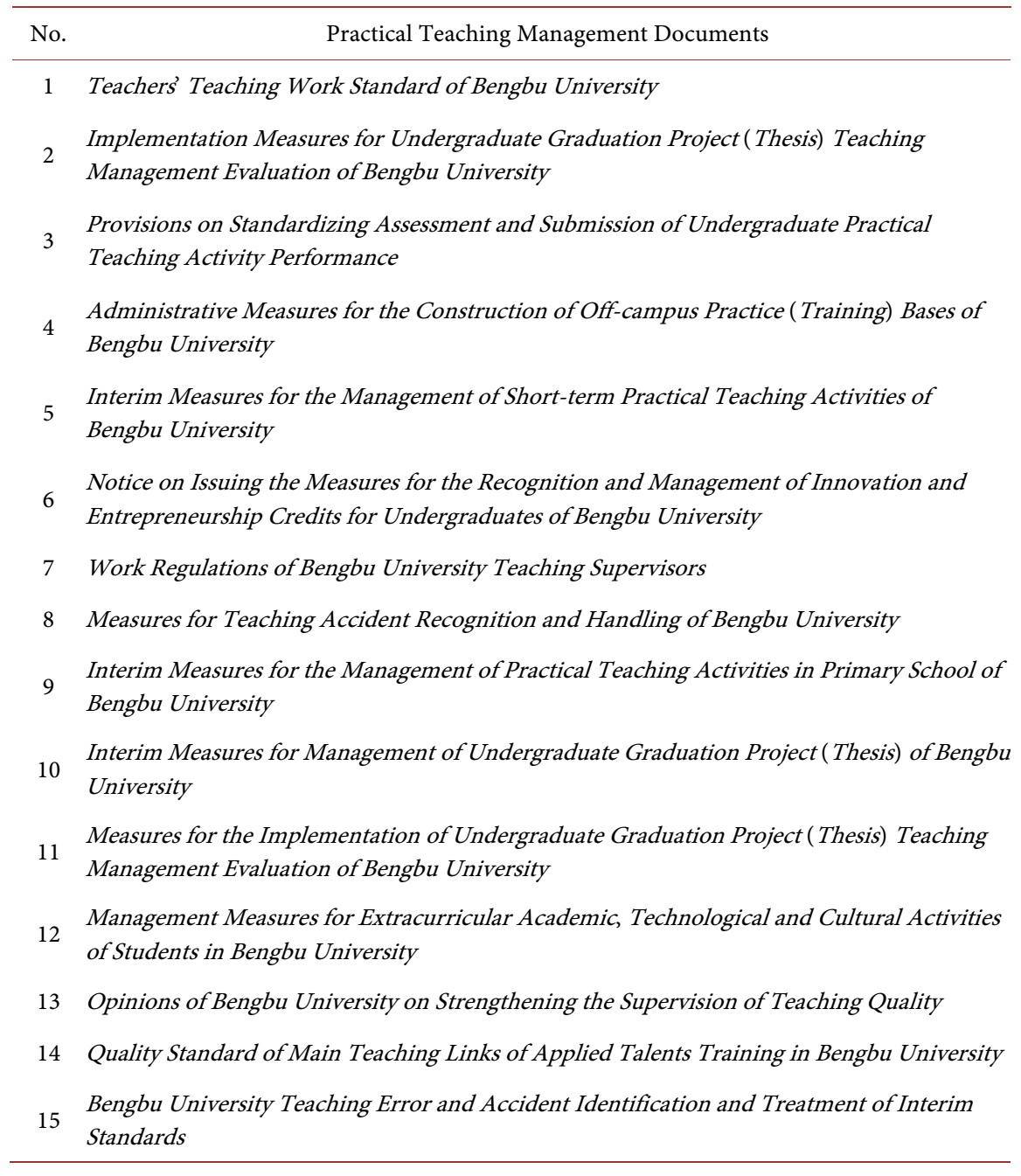

the organization and implementation of practical teaching and the evaluation of its implementation effect in detail.

Efforts have been made by Department of Food and Bioengineering to modify the talent development plan, formulate and revise the practical teaching syllabus. In practical teaching, teachers strictly observe the syllabus and teaching calendar, prepare teaching plans, and establish laboratory records to ensure the effective development of practical teaching activities.

\subsection{Sticking to Teaching Supervision Mechanism}

A complete practical teaching supervision mechanism has been established for the Food Science and Engineering major of Bengbu University. At the beginning of each semester, the college-level Teaching Supervision Group checks how the practical teaching syllabus and teaching calendars have been formulated and improved, and also how the guidance materials and teaching materials have been proposed. In the middle of the semester, they further review whether the teachers have fulfilled the practice teaching in strict accordance with the teaching ca- 
lendar, and spot check the application of teaching methods, the use of instruments and equipment, and also the discipline of practical teaching and the student management. At the end of the semester, they verify the internship report and grade evaluation, preparation and filing of the teaching materials among others. Problems existing in the practical teaching projects can be identified through the above inspection, thus urging teachers to standardize the practical teaching activities.

Further, all academic tutors in Department of Food and Bioengineering have been mobilized to participate in supervising teaching and study style since 2020, in addition to the normal practical teaching supervision, in order to practice the education idea of "All Staff Education, Whole-Process Education, All-Round Education", and to enhance the role of academic tutors in the construction of academic atmosphere. Specifically, 3 - 4 academic tutors supervise the teaching and study style on practical teaching weekly, and offer timely feedback on the supervision results, creating a favorable atmosphere for all staff to take part in the construction of teaching and study style, and forming an ideal education environment and learning atmosphere.

\section{Quality Standard System of Practical Teaching}

\subsection{Clarifying Training Objectives of Practical Teaching}

To better clarify and develop the training objectives of practical teaching, the Department of Food and Bioengineering of Bengbu University enrolled visits to a mass of employers and previous graduates to grasp the needs of enterprises and the job skills needed by the current students. On such basis, it revises the talent development program of the major, trains objectives of practical teaching, corrects the content of practical teaching, and optimizes the management of practical teaching, thereby finally trains the application-oriented high-level professional talents in accord with the needs of enterprises. For instance, innovation and entrepreneurship education and social responsibility education practice, with 4 credits respectively, were brought into the practical teaching in revising the 2018 talent development program of Food Science and Engineering major, which significantly contributed to the training of students' innovation and entrepreneurship ability and sense of social responsibility.

\subsection{Formulating the Quality Standard of Practical Teaching}

The Department of Food and Bioengineering has launched a set of quality standards for practical teaching as per the major training objectives so as to cultivate students' ability to analyze and solve problems, such as Quality Standard for Main Teaching Links of Applied Talents Training in Bengbu University. It has also formulated assessment standards based on the characteristics of various practical teaching courses, and set rules for the organizing, planning, implementing, monitoring and evaluating of practical teaching project, such as Measures for Classroom Teaching Quality Evaluation of Bengbu University, Measures 
for the Implementation of Online Teaching Evaluation of Bengbu University, and Measures for the Management of Teachers' Learning Evaluation of Bengbu University.

Moreover, the teaching contents are optimized for the Food Science and Engineering major in terms of major experiment, $\mathrm{R} \& \mathrm{D}$ comprehensive training, course designing, major practicing and training, graduation practicing and graduation project launching, etc. The practice and training content has also been added and the outdated items deleted to be more suitable for the needs of enterprises.

\section{Quality Evaluation System of Practical Teaching}

Quality evaluation of practical teaching project is performed in Bengbu University once a semester generally through the following activities: teaching supervision and evaluation, teaching peer evaluation and student evaluation. The evaluation allows the university and department to collect teaching information, give feedback on the problems found to teachers, and also guide teachers to do corrections and bolster up the quality of teaching and teaching level.

\subsection{Teaching Supervision and Evaluation}

The practical teaching work plan is executed by both of the Teaching Supervision Groups in university-level and department-level to attend lectures randomly, supervise the teaching process of each practical course, and finally examine the quality of practical teaching, under the guidance of some documents, such as Opinions of Bengbu University on Strengthening the Monitoring of Teaching Quality, Outline of the Construction of Teaching Quality Monitoring and Guarantee System of Bengbu University, and Opinions of Bengbu University on the Implementation of Undergraduate Teaching Supervision. Based on that, they can review the implementation of the talent development program, teachers' teaching plans and classroom teaching (including lectures design, organization, methods, and assignments). The implementation and effect of practical teaching are checked and evaluated in the form of questionnaire survey, in-depth interview and symposium. Those Teaching Supervision Groups also participate in the graduation defense by sampling and reviewing the graduation thesis, with the aim of investigating and evaluating the quality and process management of the graduation thesis.

\subsection{Teaching Evaluation}

Teaching evaluation is grouped into department leadership evaluation and teaching peer evaluation. The college leaders attend lectures twice a semester, and the teaching peers do around 5 times for teaching and study style supervision a semester. Consequently, they can keep abreast with the practical teaching content, implementation process and teaching effect of those under evaluation. Both of them should fill out the teaching quality evaluation form in teaching 
evaluation activities held in every semester for evaluating the teaching by teachers and providing them with opinions and suggestions. For example, in the first semester of the 2019-2020 academic year, college leaders found that some teachers' practical teaching content was relatively simple, which was divorced from the needs of society and enterprises. In view of this situation, the school of food and bioengineering organized teachers to visit the surrounding first-class food enterprises, and conducted in-depth exchanges and docking with enterprises, so as to cultivate and improve the ability of young teachers to solve problems and serve the society. In the first semester of 2020-2021 academic year, great changes have taken place in the practical teaching content, reducing outdated experiments and increasing a large number of experimental teaching content close to the actual production of enterprises.

\subsection{Student Evaluation}

Students' voice should be treated as the most important sources for their acutest feelings on the quality of practical teaching. Students at the Department of Food and Bioengineering will be allowed to log in to the university's educational administration system during $16^{\text {th }}-18^{\text {th }}$ weeks of each semester, to evaluate teachers' practical teaching quality on the online teaching evaluation platform. For instance, in the first semester of the 2019-2020 academic year, students thought that there are too many confirmatory experimental projects, while there are not enough designed experiments and open experiments that can exercise students' independent thinking ability and innovation ability. After receiving those feedbacks, the Department of Food and Bioengineering organized teachers to discuss and rectify, arranged confirmatory experiments and other types of experiments alternately, and increased the proportion of class hours for designing and open experiments from about $20 \%$ to about $50 \%$ now. These promote the practical ability of students, student satisfaction has also been improved.

\section{Implementation Effect of Quality Monitoring and Evaluation System of Practical Teaching}

\subsection{Standardizing the Practical Teaching}

The quality monitoring and evaluation system of practical teaching set up by food science and engineering major actively contributes to standardizing teaching process and elevating teaching management level. The work information of various links of teaching is collected by the Department of Food and Bioengineering through various channels. For example, through the mid-term student forum held in April 2021, six pieces of opinion on practical teaching were collected, including academic atmosphere and discipline, the setting of practical teaching content, practical teaching conditions, the working attitude of teachers, etc.

Academic Affairs Office collects, sorts out and analyzes this information from various channels, with focusing on raising regulatory opinions in line with the 
quality standards of practical teaching, optimizing the content of practical teaching, and introducing and revising the rules and regulations of practical teaching management.

\subsection{Upgrading the Practical Teaching Level of Teachers}

With the help of this system, Academic Affairs Office and Department of Food and Bioengineering are enabled to timely grasp the implementation of practical teaching, review and deal with the problems in the implementation of practice teaching, render timely feedback, guide teachers to reflect on the problems, finally develop teaching methods and improve teaching level.

In the past two years, in the process of constructing and implementing the quality monitoring and evaluation system about practical teaching for Food Science and Engineering major students under the background of New Engineering, the Department of Food Science and Engineering has been approved as the Provincial Demonstration Basic Teaching and Research Office, and has undertaken more than ten experimental teaching research projects, which includes four provincial education and teaching reform and practice projects, six university teaching research projects, five scientific research projects, one provincial major special science and technology project, two provincial key research and development projects, and one the central government guides local science and technology development fund projects.

Teachers in food science and engineering have also constantly explored the reform of experimental teaching and promote the construction of experimental courses. Up to now, the teaching and research office has built four provincial quality courses, one provincial MOOC and one school-level quality courses. More than 20 papers about food professional teaching and research have been published in Chinese and English per-reviewed journals. And the department also won the Third Prize of Provincial Teaching Achievement once.

\subsection{Sharpening Students' Scientific Research and Innovation Ability}

Owing to the system, the practical teaching quality of the Department of Food and Bioengineering of Bengbu University has been enhanced in recent years, and the students' scientific research and innovation ability has been polished. In 2020 , students of food science and engineering specialty have claimed one award in The First Vocational Skills Competition of the People's Republic of China, 3 in the Seventh Industrial Design Competition of Anhui Province, 10 in The Food Design Innovation Competition of Anhui Province, 3 in The Ninth College Students' Entrepreneurship Plan Competition of Anhui Province, 2 in the Project Capital Group Meeting of Anhui Province, and one in "Internet plus" Innovation and Entrepreneurship Competition of Anhui Province. It has been granted with 6 national college students' innovation and entrepreneurship training programs and 11 provincial (Anhui Province) counterparts. 


\section{Conclusion}

The practical teaching quality monitoring and evaluation system of food science and engineering major in Bengbu University is set scientifically and properly under the background of new engineering. Under the guidance of this system, the Department of Food and Bioengineering has standardized its practical teaching, the practical teaching teachers have improved their practical teaching level, and the students have sharpened their scientific research and innovation ability.

\section{Acknowledgements}

This work was financially supported by the Major Teaching Research Projects of Anhui Provincial Education Department (2020jyxm1142).

\section{Conflicts of Interest}

The authors declare no conflicts of interest regarding the publication of this paper.

\section{References}

Department of Higher Education, The Ministry of Education (2017). Action Route of "New Engineering" Construction ("Tianjin University Action”). Research in Higher Education of Engineering, No. 2, 24-25. (In Chinese)

Han, Z. X., Wang, H. X., \& Cao, C. L. (2011). On the Construction of Quality Monitoring and Evaluation System of Practical Teaching in Newly-built Colleges. Education and Teaching Research, 25, 69-72. (In Chinese)

Liu, N., Tang, M., \& Wang, M. L. (2019). A Discussion on the Efficiency of Teaching Quality Monitoring and Evaluation System of Newly Established Undergraduate College-A Case Study on Xi'an Aeronautical University. Xi'an University of Architecture and Technology (Social Science Edition), 38, 94-99. (In Chinese)

Liu, Y. L., Pan, M. Q., \& Pan, L. (2011). Research on Construction of Systems for Quality Monitoring of Practice Teaching and Appraisal Target. Experimental Technology and Management, 28, 19-21+24. (In Chinese)

Liu, Y., \& Wang, Z. R. (2016). On the Construction of Out-of-School Practice Teaching Quality Monitoring System for Application-Oriented Majors. Journal of Neijiang Normal University, 31, 85-88. (In Chinese)

Niu, G. C., Yang, H. Z., \& Wang, X. Q. (2013). Construction and Implementation of Innovative Practical Teaching System of Food Science and Engineering Major. Food \& Machinery, 29, 270-272. (In Chinese)

Xian, X. F., Li, J. X., \& Zeng, H. (2018). Research and Practice on Teaching Quality Monitoring and Evaluation System in "Internet Plus" Era. Journal of Suzhou Vocational University, 29, 43-47. (In Chinese)

Xiang, Y. Y., Yin, P. F., \& Zhang, Y. C. (2020). Construction of Quality Monitoring and Evaluation System for Practical Teaching of Biological Science Major in View of Emerging Engineering Education-A Case Study of Chuzhou University. Journal of Huangshan University, 22, 125-128. (In Chinese) 